L. Z. Rebukha ${ }^{1}$

ORCID https://orcid.org/0000-0002-0054-0651

Nicolae Rambu ${ }^{2}$

ORCID https://orcid.org/0000-0003-4593-1477

Scopus Author ID 36140441000

${ }^{1}$ Ternopil National Economical University

${ }^{2}$ A. Cuza University, Iasi, Romania

\title{
THE IMPORTANCE OF TRAINING TECHNOLOGIES IN THE FORMATION OF INTERCULTURAL COMPETENCE OF FUTURE SOCIO- HUMANITARIAN PROFESSIONS
}

\author{
Л. 3. Ребуха' ${ }^{1}$ Ніколає Рамбу른 \\ ${ }^{1}$ Тернопільський національний економічний університет \\ ${ }^{2}$ Ясський університет імені А. Кузи, Ясси, Румунія
ЗНАЧИМІСТЬ ТРЕНІНГОВИХ ТЕХНОЛОГІЙ У ФОРМУВАННІ СОЦІОГУМАНІТАРНИХ ПРОФЕСІЙ \\ МІЖКУЛЬТУРНОЇ КОМПЕТЕНТНОСТІ МАЙБУТНІХ ФАХІВЦІВ
}

\begin{abstract}
The problem of formation of intercultural competence in future specialists of socio-humanitarian sphere in higher education institutions is actualized in the article. The review of modern scientific approaches to the definition of the term "intercultural competence" is made. Intercultural competence is attributed to the group of leading competences of both the personality and professional competences of the future specialist of socio-humanitarian professions. The content of intercultural competence with personal, informational and activity components is presented; its structural components including general cultural and cultural-specific knowledge, professionallyoriented skills and abilities, intercultural psychological perception, personal reflection and ways of subjective interaction have been identified and characterized. The levels and stages of personal growth of students towards the formation of a multicultural personality are revealed. The intercultural competence of the future specialist is presented as an integrative quality, which ensures his/her readiness for professional activity in the conditions of ethno-cultural diversity of the modern society.

The importance of using cultural-directed socio-psychological training for the formation of intercultural competence in groups of students of other cultures, which consistently produces motivation and knowledge and enables their practical application in the students group in interaction with representatives of other cultures; contributes to the resolution of conflicts arising from ethnic diversity; generates positive-personal reflective processes to gain experience of professional interaction with representatives of other cultures; projects his/ her own experience in the following situations of future professional activity, are described in the article.

The criteria of forming (motivational, cognitive, activity, reflexive) professional intercultural competence of specialists in the process of using training technologies are described.
\end{abstract}

Key words: intercultural competence; future specialists; socio-psychological training; multicultural group.

Анотація. У статті актуалізовано проблему формування міжкультурної компетентності у майбутніх фахівців соціогуманітарної сфери в закладах вищої освіти. Зроблено огляд сучасних наукових підходів до визначення поняття «міжкультурна компетентність». Віднесено міжкультурну компетентність до групи провідних компетентностей як особистості, так і професійних компетентностей майбутнього фахівця соціогуманітарних професій. Подано змістове наповнення міжкультурної компетентності із особистісними, інформаційними та діяльнісними складовими; встановлено та схарактеризовано її структурні компоненти, до яких віднесено загальнокультурні і культурно-специфічні знання, професійно-спрямовані вміння і навички, міжкультурне психологічне сприйняття, особистісну рефлексію та способи суб'єктного взаємодіяння. Розкрито рівні та етапи особистісного зростання студентів у напрямі формування мультикультурної особистості. Міжкультурну компетентність майбутнього фахівця представлено як інтегративну якість, котра забезпечує його готовність до професійної діяльності в умовах етнокультурної розмаїтості сучасного соціуму.

У статті описано важливість використання загальнокультурного соціально-психологічного тренінгу для формування міжкультурної компетентності в інокультурних студентських групах, що послідовно продукує мотивацію і знання та уможливлює їхнє практичне застосування у студентській групі під час взаємодії з представниками інших культур; сприяє розв’язанню конфліктних ситуацій, що виникають на грунті етнічної різноманітності; генерує позитивно-особистісні рефлексивні процеси

( ) L. Z. Rebukha, Nicolae Rambu 


\section{Materials of International Scientific and Practical Conference \\ "PROFESSIONAL AND COMMUNICATION CULTURE OF THE FUTURE DOCTOR: LINGUISTIC, PEDAGOGICAL AND PHILOSOPHICAL ASPECTS”}

щодо отримання досвіду професійної взаємодії з представниками інших культур; проектує власний досвід у наступні ситуації майбутньої професійної діяльності.

Описано критерії сформованості (мотиваційний, когнітивний, діяльнісний, рефлексивний) професійної міжкультурної компетентності фахівців у процесі використання тренінгових технологій.

Ключові слова: міжкультурна компетентність; майбутні фахівці; загальнокультурний соціально-психологічний тренінг; полікультурна група.

Introduction. Modern societies are characterized by high social mobility, ethnic and cultural diversity in many fields of professional activity. Future specialists with higher education are competing in a labor market that has now gained a global dimension. Large global companies need specialists who are able to effectively interact within a multicultural environment and avoid misunderstandings on an interethnic basis to solve professional problems. These trends are reflected in the training of specialists in institutions of higher education. This problem is particularly relevant in the process of globalization and internationalization of education. Academic mobility of students and teachers promotes collaboration and inter-university communications in the field of education, professional development, exchange of experience, joint scientific and applied researches, etc. There is a natural formation of intercultural competence in the future specialists of socio-humanitarian sphere due to the internationalization of education, but this is not enough, because it requires its purposeful formation in institutions of higher education.

The aim - to form the intercultural competence of specialists of socio-humanitarian sphere on the basis of training technologies.

Theoretical framework. Researches of recent years has shown that there is a problem in today's world in the interaction between representatives of different ethnic groups, in trusting and tolerance to each other.

Ethnically diverse composition of the country's population, a significant number of newly arrived students (nationals of other countries), their national and situationally-determined psychological characteristics place new demands on the professional competence of future specialists in the socio-humanitarian field. Forming the skills of interacting with representatives of different nations and nationalities is an important task of professional communities, whose members must effectively interact in the global space. Intercultural competence is now credited to the group of main professional competences of the modern specialist.

The analysis of scientific literature has revealed different approaches to the interpretation of the concept and the definition of the component composition of "intercultural competence". The existence of a large amount of definitions of intercultural competence should be deployed in the logic of movement from competence as meaningful filling of activity to competence as a set of acquired professional qualities of a person, which ensure the performance of relevant activity.

The intercultural competence of specialists of different directions of training is characterized as a main category, which reveals the essence of a democratic society, presupposes the preservation of a tolerant globalized society, meets the modern requirements of the labor market, constant social and informative-economic transformations, etc. in the scientific works of T. Atroshchenko, I. Bekh, O. Bida, I. Zyuzyun, V. Kremin, T. Makarova, S. Mikheeva, N. Nychkalo, I. Pluzhnik, O. Pometun, O. Pryshlyak, O. Snigovska, O. Frolova, T. Schmidt and others. According to O. Sadokhin, intercultural competence for a specialist is a set of effective knowledge, skills and abilities, according to which an individual is able to successfully communicate with persons from other cultures at a high professional level [5]. Scientist $\mathrm{K}$. Yuryev proves that intercultural competence serves as a basic indicator of the quality of education, acts as its integrative professional-personal component with a synthesized set of socio-humanitarian knowledge and is determined by the multifaceted readiness of the future specialist to participate in intercultural communication [7]. O. Baibakova, O. Pryshlyak, O. Snigovskaya and $\mathrm{N}$. Rambu consider the intercultural competencies of specialists as an important tool in achieving success in the process of intercultural interaction and distinguish its effective criteria: successful fulfillment of professionally oriented tasks; the ability to engage in a constructive dialogue between cultures, which sometimes requires a high level of knowledge of foreign languages, history and culture of other nations; the ability to build tolerant social relationships between representatives of other cultures; ability to carry out personal identification with foreign specialists and clients of social institutions [1-4, 6, 10].

In our understanding, intercultural competence as a systemic formation serves as a set of knowledge, skills, abilities and motivational-valuable motives that 
facilitate effective communication with representatives of another culture in the process of intercultural interaction. On the other hand, intercultural competence includes knowledge of the life habits, customs, and attitudes of the society with other culture, which form the individual and group settings, behaviors, nonverbal components of interaction, national-cultural traditions and values of the future specialist. Its structure includes the following components:

- general-cultural and cultural-specific knowledge;

- practical professional-oriented skills and ways to interact subjectively;

- intercultural psychological perception in order to achieve goals and personal self-realization of interests.

Bennet J. M. considers the process of acquisition of foreign culture and developing intercultural competence [8]. The scientist has distinguished six levels that reflect the attitude of the future specialist to the differences between the native and other cultures and the corresponding six stages of his personal growth in this direction. The first three are ethnocentric. Each of them is personified and characterized by: a) "denial of differences" in cultures; b) "protection against differences" with judgments in favor of his/ her own culture or ethnic group; c) "minimizing differences" with estimates that differences are present in different cultures but they are insignificant. Three others are ethno relativistic, which are directed at: a) "recognizing differences" in culture in relation to his/her own; b) "adaptation to differences" between cultures and ethnicities, which implies the ability not only to recognize these differences but also to act accordingly; the formation of self-restructuring skills from one behavioral model to another; c) "integration" of the person into the other culture, with the aim of bringing together or interpenetrating different cultures; adopting different worldviews that underlie cultural variations in behavior; formation of a multicultural personality. At the same time, a large number of future specialists are in one of the ethnocentric stages of everyday life.

A general-cultural socio-psychological training is an effective method of forming intercultural competence in high school students. Considering its specific tasks, all stages of training are directed at the development and improvement of personal thought, the development of positive emotions and conscious personal behavior. Such intercultural competence, which stimulates external polyglot, forms a triad in the form of knowledge, skills and social attitudes. Typologization of intercultural socio-psychological training into the general-cultural, directed at enhancing intercultural perception in general, and cultural-specific, which involves the preparation of a future specialist to interact with the media of a particular culture, gives impetus to the pervasive influences on the knowledge of professional interaction of other cultures.

Accordingly, the organization of the educational process requires mastery of intercultural competences by teachers and students, as most academic groups are now multicultural. Therefore, the development of training technologies must take into account the ethnocultural composition of the group.

R. Brislin outlines a complete typology of generalcultural socio-psychological trainings in the field of intercultural communication, which is used effectively in institutions of higher education [9]. These include:

a) training of self-awareness - knowledge of future specialists of his/her own culture;

b) cognitive training - getting maximum information about other cultures;

c) attribution training - acquisition of skills of explanation of the causes, situations and actions from the point of view of other culture;

d) behavioral training - training of business skills that are necessary for professional activity with persons of another culture;

e) situational training - the reproduction and analysis of specific intercultural contacts, discussion of problems arising from such interactions.

Effectively conducted training influences the intensive formation of positive dynamics of intercultural competence, as it actualizes knowledge of one's own culture, facilitates the acquisition of information about other cultures and peculiarities of behavior of its representatives and adapts future professionals to interaction in a foreign language environment. The criteria for the formation of professional intercultural competence in the training process are:

- motivational. It is displayed in interest and desire for intercultural interaction; setting and realizing the goals of such interaction; motivation to achieve the purpose and increase the level of intercultural competence;

- cognitive. It is characterized by the presence of knowledge, skills and abilities, that are necessary for successful intercultural professional interaction and the ability to apply them skillfully in future new conditions; by ability to anticipate intercultural conflicts, effectively analyze them and find ways to prevent and overcome them; 


\section{Materials of International Scientific and Practical Conference \\ "PROFESSIONAL AND COMMUNICATION CULTURE OF THE FUTURE DOCTOR: LINGUISTIC, PEDAGOGICAL AND PHILOSOPHICAL ASPECTS”}

- active. It reveals the application of intercultural knowledge, skills and abilities in practice-oriented situations of intercultural interaction; identifies the ability to assist in adaptation to intercultural society;

- reflexive. It reflects the acquisition of analytical and evaluation-informative skills by future specialists; reveals skills to carry out personal-professional intercultural reflection, self-control, self-esteem, etc.

Training of intercultural competence as one of the effective educational methods practices real-time behavioral communicative attitudes and students' skills, develops their ability to listen to the interlocutor and confidently behave publicly in the presence of other people. Its main task is to help building an effective model of relations with communication partners, to prevent conflicts, to overcome the causes of complica-

\section{List of literature}

1. Байбакова О. О. Формування міжкультурної компетентності майбутніх фахівців соціальної роботи у вищих навчальних закладах США : дис. ... канд. пед. наук: 13.00.04 / О. О. Байбакова. - Тернопіль, 2017. - 195 с.

2. Пришляк О. Ю. Міжкультурна компетентність у контексті діалогу культур / О. Ю. Пришляк // Вісник Луганського національного університету імені Тараса Шевченка. Педагогічні науки. - 2019. - № 6 (329), ч. 2. - С. 228-238.

3. Ребуха Л. 3. Инновационные технологии в профессиональной подготовке будущих социальных работников / Л. З. Ребуха // Теория и методика профессионального образования : сборник научных статей. - Минск : РИПО, 2017. - Вып. 4, ч. 1. - С. 112-117.

4. Ребуха Л. 3. Сутнісний аналіз рівнів методологування науково-професійної соціальної роботи / Л. 3. Ребуха // Science Rise: Pedagogical Education. - 2017. № 2 (10). - C. 13-18.

5. Садохин А. П. Межкультурная компетентность: понятие, структура, пути формирования / А. П. Садохин // Журнал социологии и социальной антропологии. 2007. - T. X, № 1. - С. 125-139.

\section{References}

1. Baibakova, O.O. (2017). Formuvannia mizhkulturnoi kompetentnosti maibutnikh fakhivtsiv sotsialnoi roboty u vyshchykh navchalnykh zakladakh SShA [Formation of intercultural competency of future specialists of social work at the institutions of higher education of USA]. Candidate's thesis. Ternopil [in Ukrainian].

2. Pryshlyak, O.Yu. (2019). Mizhkulturna kompetentnist u konteksti dialohu kultur [Intercultural competence in the context of dialogue of cultures]. Visnyk Luhanskoho natsionalnoho universytetu imeni Tarasa Shevchenka. Pedahohichni nauky - Bulletin of Luhansk Taras Shevchenko tions in the communication process, to form communicative habits and behaviors acceptable to different cultures.

Conclusions and Prospects for Research. The use of training technologies combines personal, informative and activity aspects, which makes it one of the most effective methods in the formation of the intercultural competence of future specialists in institutions of higher education. This approach to the educational process of this direction allows not only to form intercultural competence among high school students, but also to comprehensively develop a diagnostics of the level of formation of this competence and to find the trajectory of individual learning based on the appropriate use of training technologies, which will be the purpose of our further scientific exploration.

6. Сніговська О. Професійна іншомовна підготовка як важливий чинник формування міжкультурної компетентності майбутніх фахівців із міжнародних відносин / О. Сніговська // Наукові записки Національного університету «Острозька академія». - 2015. - Вип. 54. С. 314-317.

7. Юр’єва К. А. Компетенція, компетентність, міжкультурна компетентність учителя: сутність і зміст / К. А. Юр’єва, О. М. Тіщенко // Засоби навчальної та науково-дослідної роботи. - 2014. - № 42. - С. 169-185.

8. Bennet J. M. Developing intercultural sensitivity / J. M. Bennet, M. J. Bennett // Handbook of intercultural training. Thousand Oaks, CA: Saga, 2004. - P. 147-165.

9. Brislin R. W. Intercultural communication training: An introduction / R. W. Brislin, T. Yoshida. - Thousand Oaks, 1994.

10. Râmbu N. Comunicare interculturală / N. Râmbu. Editura Universității „Alexandru Ioan Cusa”din JASI. 2020. - 225 p.

National University. Pedagogical Sciences, 6 (329), 2, 228 238 [in Ukrainian].

3. Rebukha, L.Z. (2017). Innovatsionnye tekhnologii $\mathrm{v}$ professionalnoy podgotovke budushchikh sotsialnykh rabotnikov [Innovative technologies in the professional training of future social workers] Sbornik nauchnykh statey. Minsk - Collection of Scientific Articles. Minsk, 4, 1, 112117 [in Russian].

4. Rebukha, L.Z. (2017). Sutnisnyi analiz rivniv metodolohuvannia naukovo-profesiinoi sotsialnoi roboty [Substantial analysis of the levels of methodology of 


\section{Materials of International Scientific and Practical Conference \\ "PROFESSIONAL AND COMMUNICATION CULTURE OF THE FUTURE DOCTOR: LINGUISTIC, PEDAGOGICAL AND PHILOSOPHICAL ASPECTS”}

scientific-professional social work]. Science Rise: Pedagogical Education, 2 (10), 13-18 [in Ukrainian].

5. Sadokhin, A.P. (2007). Mezhkulturnaya kompetentnost: ponyatie, struktura, puti formirovaniya [Intercultural competence: concept, structure, ways of formation]. Zhurnal sotsiologii i sotsialnoy antropologii - Journal of Sociology and Social Anthropology, 10 (1), 125-139 [in Russian].

6. Snigovska, O. (2015). Profesiina inshomovna pidhotovka yak vazhlyvyi chynnyk formuvannia mizhkulturnoi kompetentnosti maibutnikh fakhivtsiv iz mizhnarodnykh vidnosyn [Professional foreign language training as an important factor for forming intercultural competence of future specialists in international relations] Naukovi zapysky Natsionalnoho universytetu "Ostrozka akademiia" - Scientific Notes of the National University "Ostroh Academy”, 54, 314-317 [in Ukrainian].
7. Yureva, K.A., \& Tishchenko, O.M. (2014). Kompetentsiia, kompetentnist, mizhkulturna kompetentnist uchytelia: sutnist i zmist [Competency, competence, intercultural competence of the teacher: Essence and content]. Zasoby navchalnoi ta naukovo-doslidnoi roboty - Funds of Educational and Research Work, 42, 169-185 [in Ukrainian].

8. Bennett, J.M., \& Bennett, M.J. (2004). Developing intercultural sensitivity: An integrative approach to global and domestic diversity. Handbook of Intercultural Training. Thousand Oaks, CA: Sage.

9. Brislin, R., \& Yoshida, T. (1994). Intercultural communication training: An introduction (Vol. 2). Sage.

10. Râmbu, N. (2020). Comunicare interculturală. Editura Universității “Alexandru Ioan Cusa”din JASI.

\footnotetext{
E-mail address for correspondence: 1_rebukha@ukr.net
} 